\title{
The Usage of BIOM3G-Biofertilizer to Improve and Support Sustainability of Land System of Independent Oil Palm Smallholders
}

\author{
Teguh Adiprasetyo ${ }^{1}$, Bambang Purnomo ${ }^{2}$, Merakati Handajaningsih ${ }^{3}$, Hidayat $^{4}$ \\ Faculty of Agriculture, University of Bengkulu, Jl. WR. Supratman, Bengkulu, 38122, Indonesia \\ E-mail: ${ }^{1}$ teguhadi@yahoo.com, ${ }^{2}$ bpurnomo51@yahoo.co.id, ${ }^{3}$ merakati@gmail.com, ${ }^{4}$ hidayathusnan04@yahoo.com
}

\begin{abstract}
Soil fertility is one of the key success factors for managing independent smallholder oil palm plantation sustainably. To improve soil fertility, the smallholder oil palm farmers depend highly on the chemical fertilizer which emits greenhouse gases $\mathrm{N}_{2} \mathrm{O}$ and are fragile to chemical fertilizer shortage. This dependency to chemical fertilizer and increased price of chemical fertilizer may cause some independent smallholder plantations are neglected and fruitless due to late nor absence of fertilizers. In the country with plentiful of oil palm plantations, biomass of oil palm empty fruit bunch should be considered as a sustainable source of organic fertilizers. This research examined the effect of dosage of composted oil palm empty fruit bunch enriched with multi functions multi microbial biofertilizer implanted within the soil below canopy edges of oil palm plants towards the growth and yield of oil palm plants. The treatments consisted of 3.5, 7.0, and 10.5 ton biofertilizer/ha and standard chemical fertilizer treatment as control. Each treatment was applied on ten plants. The results of this study showed that the biofertilizer application at 10.5 ton/ha improved the quality of soil better than other treatment of biofertilizer and standard chemical fertilizer. The production yield of fresh fruit brunches of 10.5 ton biofertilizer/ha treatment was 31.5 ton/hectare/year. If the oil palm production is compared to farmer's practice that produces 24 ton/hectare/year, these research results may promote better organic wastes management of oil palm plantation to better nourish the plants and improve sustainability of oil palm land system.
\end{abstract}

Keywords — biofertilizer, oil palm, palm empty fruit bunch, independent oil palm smallholder

\section{INTRODUCTION}

Palm oil has become an important economic commodity, particularly in Sumatra and Kalimantan. Currently the production of palm oil has contributed nearly $50 \%$ of the total percentage of the value of Indonesian exports, as well as the largest manufacturer and exporters of CPO (crude palm oil) with production of 23 million tons/year [1]. Bengkulu province also has developed this commodity on a large scale, primarily by people independently in MukoMuko, North Bengkulu, Bengkulu Central, Seluma, South Bengkulu and Kaur Regency. However, with extensive smallholding, there are various problems faced by oil palm growers in the province of Bengkulu, possibly more complex than other palm oil production centers. The problems are among others, the scarcity of supply of chemical fertilizers that can be happened at any time and barriers related application season. These problems may negatively affect the productivity of oil palms. Therefore, the development of culture systems further ensure the continuity of production with the usege of avalable local resources, such as waste organic materials which is plenty in the area of oil palm plantations is needed.

Reference [2] shows that the level of soil compactness and the soil clay content in oil palm plantations are generally very high. In addition, the soils are low $\mathrm{pH}$ and organic matter content. These conditions, together with the increase of dependency on chemical fertilizers may lead to the increasingly impoverish the soil to support oil palm production sustainably. It will also eventually affect the social economic welfare of the small holder farmers. If oil palm plantations are not fertilized, the fruit production is also very low or even not fruiting at all. Eventually, farmers may abandon their farm because of the low productivity.

Lately, improvement of soil fertility have been carried out with the supplement of organic matter. The addition of organic materials on agricultural land reported effective to prevent erosion, also increased crop production and resistance to environmental stress [3], [4]. Application of organic manures is generally given as a mulch [5] or a mixture of the growing media, especially in horticultural crops of vegetables. The addition of organic matter can also affect the microbial composition of the soil [6] - [9]. Annual crops such as oil palm, the addition of organic matter is 
mostly in the form of empty fruit bunches and shredded fronds abundance in the plantations. However, this source of organic matter takes a long time to decompose. Introduction of microbes that degrade organic matter is likely to accelerate the decomposition process of added empty fruit brunches and increase the availability of nutrients for growth and crop production. For that purpose, the use of organic waste enriched with multi-use multi microbes (BIOM3G) is expected to accelerate the process of decomposition of organic matter and can immediately improve or maintain soil fertility of oil palm smallholders. With the application of BIOM3G especially to unproductive oil palm plantation due to not properly fertilized, it is expected to be productive again and increase production so that the farmer welfare will also increase.

This study specifically aims to test the ability of multimicrobial biofertilizer multi-use (BIOM3G) to improve soil fertility and substitute the use of chemical fertilizers partially or completely through the addition of empty fruit bunches organic waste material to support the growth of palm oil production in oil palm cultivation systems that are environmentally friendly. Furthermore, it is expected that the use of BIOM3G will reduces farmer dependency of external chemical inputs.

\section{METHODS}

Research was carried out in May to November 2013 in oil palm farm in the village of Jum'at, Talang Empat District, Central Bengkulu Regency and Laboratory of Plant Protection and Soil Sciences, Faculty of Agriculture University of Bengkulu. BIOM3G starter multiplication was done using empty fruit bunches of oil palm waste organic material considering it was more readily available and abundance than other organic matter. In addition, oil palm empty fruit bunches were considered as major waste products from the palm oil industry. The composted empty fruit bunches was then applied on crops according to dose treatments.

Testing the effectiveness of BIOM3G conducted on 10 crops for each treatment. Treatments consisted of three (3) dosage of BIOM $3 \mathrm{G}$ and SOP, namely $\mathrm{A}=25 \mathrm{~kg}$ BIOM3G/plant (3.5 tons/ha), B = 50kg BIOM3G/plant $(7.0$ tons/ha), C = dose of chemical fertilizer SOP (1.5 kg Urea, 2 $\mathrm{kg}$ and $1.5 \mathrm{~kg}$ dolomite MOP per plant) and $\mathrm{D}=75 \mathrm{~kg}$ BIOM3G/plant (10.5 tons/ha). BIOM3G was applied once in every crop samples for all treatments, by digging the soil near the root tip on $1 / 2$ circle separated into 3 sections the same depth of $30 \mathrm{~cm}$, width $15 \mathrm{~cm}$, and BIOM $3 \mathrm{G}$ in sacks placed there in.

Soil characteristics were analyzed before treatments and 3 months after treatments. Observed vegetative variables, such as the number of leaves, plant height, and crop chlorophyll content were observed since the application three monthly. While production variables such as the number of fruit bunches harvested, harvested bunch weight, total weight of bunches harvested of each harvest were observed. Data were analyzed statistically and if significant then further tested to detect the smallest real difference and the best dosage interval.

\section{RESULTS AND DISCUSSION}

\section{A. Soil Characteristics}

Changes in soil properties observed by comparing the properties of the soil prior to treatment with the characteristics of the soil 12 weeks after treatment and fertilization with BIOM3G SOP. Statistical analysis showed that the characteristics of the soil before and after treatment were not significantly different, except for the electrical conductivity (EC) and soil phosphorus content. The electrical conductivity was higher after treatment, increased from an average of 48 microseconds/cm to 74 microseconds $/ \mathrm{cm}$. While the $\mathrm{P}_{2} \mathrm{O}_{5}$ content of the soil increased from $5 \mathrm{mg} /$ $\mathrm{kg}$ before treatment increased to $8.4 \mathrm{mg} / \mathrm{kg}$. In general, treatment and fertilization BIOM3G SOP did not result in significant changes in soil acidity. However, there was a trend of higher $\mathrm{pH}$ after treatment BIOM3G-75 kg/plant and fertilization treatments compared BIOM3G SOP-25 and 50 $\mathrm{kg} /$ plant. In conditions of higher soil $\mathrm{pH}$, the exchange of cations in the soil to the roots could continue to a maximum, so that nutrient needs of the plants were supplied to the fullest. In contrast to the condition when the soil $\mathrm{pH}$ was lower. It would be more adsorbed cations were exchanged with aluminum and hydrogen ions so that supply of nutrients for plant growth was minimal [10].

The results also showed that soil characteristics were not significantly different due to the different treatment doses of BIOM $3 G$ and fertilization of SOP, except on the content of exchangeable aluminum and hydrogen. The content of exchangeable $\mathrm{Al}$ and $\mathrm{H}$ in the treatment of BIOM3G 25 and $50 \mathrm{~kg} / \mathrm{plant}$ was significantly different with treatment BIOM3G-75 kg/plant. The content of exchangeable $\mathrm{Al}$ and $\mathrm{H}$ in the treatment BIOM3G $75 \mathrm{~kg} /$ plant was not significantly different from SOP fertilizer treatment. Although, the trend in the treatment BIOM3G-75 kg/plant contained Al-dd (3.8 me / 100g) and H-dd (1.1 me / 100g) smaller compared to most other treatments. This phenomenon indicates that the addition of $75 \mathrm{~kg}$ BIOM3G per plant in soil have similar impact on the declining exchangeable $\mathrm{Al}$ and $\mathrm{H}$ with dolomite application of $1.5 \mathrm{~kg}$ per plant in the treatment of SOP. Treatment of BIOM3G and SOP were not significantly different in influencing the content of exchangeable potassium, the overall content of the exchangeable $\mathrm{K}$ tended to be higher after the treatment applied and the content of exchangeable $\mathrm{K}$ was the highest in treatment of BIOM $3 \mathrm{G}-75 \mathrm{~kg} /$ plant.

Thus, fertilizing soil with BIOM3G was able to improve soil properties, especially increasing the electrical conductivity and phosphate content as well as reduce the content of exchangeable aluminum and hydrogen. Applications of composted empty fruit bunches with BIOM3G could increase the content of exchangeable potassium and other cations as indicated by differences in electrical conductivity. However, regarding to the mechanism of nutrient supply to the plants affected by BIOM3G, it still needs to be further investigated.

\section{B. Vegetative Variables}

Vegetative variables analyzed were the number of leaves, plant height and leaf khlorofil content as shown in Table 1. The average of all crops in all experimental treatments had 
total leaves, plant height, leaf khlorofil content were not statistically different. However, the application of BIOM3G $75 \mathrm{~kg} / \mathrm{plant}$ tended to have higher leaf chlorophyll content compared to the application of SOP and treatment of BIOM3G 25 and $50 \mathrm{~kg} / \mathrm{plant}$. This supports the notion of BIOM3G effectiveness in maintaining the vegetative growth of crops, including the formation of leaf as the plants treated treated with chemical fertilizer (SOP).

TABLE I

Average of Total Leaves, Plant Height, Increased Plant Height AND LEAF CHLOROPHYLL CONTENT

\begin{tabular}{|l|l|c|c|c|}
\hline No & \multicolumn{1}{|c|}{ Treatment } & Leaves & $\begin{array}{c}\text { Plant } \\
\text { Height } \\
\text { (cm) }\end{array}$ & $\begin{array}{c}\text { Leaf } \\
\text { Chlorophyll } \\
\text { Content }\end{array}$ \\
\hline A & BIOM3G-25 kg & 50 & 177 & 67.4 \\
\hline B & BIOM3G-50 kg & 51 & 164 & 69.8 \\
\hline C & SOP & 47 & 218 & 67.3 \\
\hline D & BIOM3G-75 kg & 46 & 209 & 70.1 \\
\hline
\end{tabular}

\section{Production Variables}

Production variables observed included number of harvested fruit bunches, average weight of fresh fruit bunches (FFB) per harvest and total weight of fresh fruit bunches per plant as presented in Table 2 and total weight of fresh fruit brunches of samples for 5 months. Statistically, BIOM $3 \mathrm{G}$ and SOP treatment had not influence differently on the observed production variables. The total weight of fresh fruit brunches of 10 samples per treatment was not analyzed statistically and presented visually in Figure 1.

The results of data analysis showed that the average number of fruit bunches harvested per plant over the periode of 5 months were not affected by treatment. On this variable, the number of bunches harvested per plant on average for 5 months was between 6 and 7 bunches. The average number of bunches harvested also showed a similar trend to the data of average weight per harvest per plant as well as the average total weight of fresh fruit brunches of samples for 5 months. These data showed the ability of BIOM3G to replace chemical fertilizers with dosage recommendations of SOP.

The total weight of fresh fruit brunches per treatment during the period of 5 months indicated that the application of BIOM3G-75 kg/plant capable of producing $1058 \mathrm{~kg}$, followed by treatment BIOM3G $50 \mathrm{~kg} / \mathrm{plant}$ with the 942.5 $\mathrm{kg}$ (Figure 1). If the unit is converted in hectares and over the year it will produce 35.5 tons/ha/year for treatment of BIOM3G-75 kg/plant and 31.5 tons/ha/year for treatment BIOM3G $50 \mathrm{~kg} / \mathrm{plant}$. The conversion gave a very good overview of the prospects for the development and application of BIOM3G on wider oil palm farming community. However, we still need a more convincing proof of a test in scale of hectares to reconfirm the results of this study to improve and support sustainable oil palm production of independent smallholder plantation.
TABLE II

Average of Harvested Fruit Bunches, Weight Per harvest Per PLANT, AND AVERAGE OF TOTAL FRUIT BUNCHES PER PlaNT

\begin{tabular}{|l|l|c|c|c|}
\hline No & Treatment & $\begin{array}{c}\text { Harvested } \\
\text { Fruit } \\
\text { Bunches }\end{array}$ & $\begin{array}{c}\text { Weight } \\
\text { per } \\
\text { Harvest } \\
\text { (kg) }\end{array}$ & $\begin{array}{c}\text { Total } \\
\text { Weight per } \\
\text { Plant (kg) }\end{array}$ \\
\hline A & BIOM3G-25 kg & 6 & 18 & 87 \\
\hline B & BIOM3G-50 kg & 7 & 20 & 94 \\
\hline C & SOP & 6 & 17 & 67 \\
\hline D & BIOM3G-75 kg & 7 & 21 & 106 \\
\hline
\end{tabular}

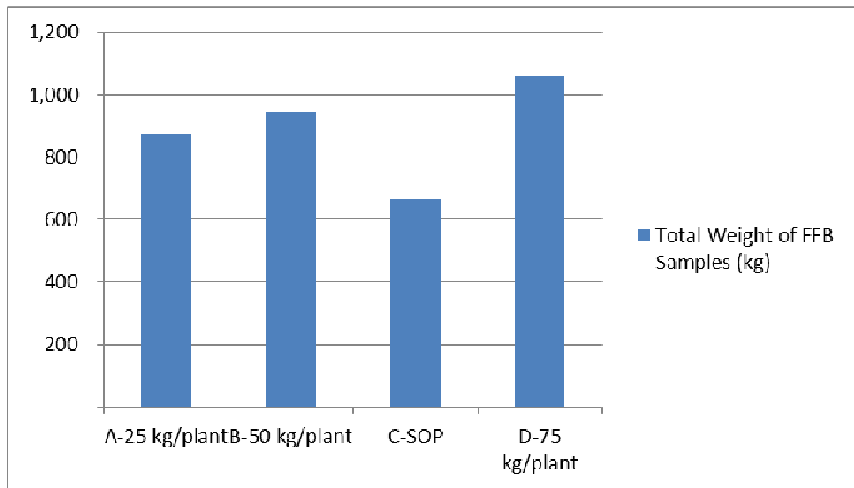

Fig. 1 Total weight of fresh fruit bunches of samples for 5 months

\section{CONCLUSIONS}

Aplication of BIOM3G and chemical SOP did not influence significantly on the observed vegetative variables, namely the number of leaves, plant height and leaf chlorophyll content. However, the application of BIOM3G $75 \mathrm{~kg} /$ plant tended to influence better than the application of chemical fertilizer SOP, BIOM3G-25 and $50 \mathrm{~kg} /$ plant. Similarly, the observed production variables included the number of fruit bunches harvested, average weight of fresh fruit bunches (FFB) per harvest and total weight of fresh fruit brunches of samples were not statistically different. However, this condition still indicated the ability of BIOM3G to replace chemical fertilizer application of recommendation dose of chemical fertilizer (SOP).

The total weight of the fresh fruit brunches of sample treatment during the period of 5 months demonstrated that the application of BIOM3G-75 kg/plant capable of producing $1058 \mathrm{~kg}$, followed by treatment of BIOM3G 50 $\mathrm{kg} /$ plant with the production of $942.5 \mathrm{~kg}$. The conversion of units would produce fresh fruit bunches weighing of 35.5 tons/ha/year for treatment of BIOM3G-75 kg/plant and 31.5 tons/ha/year for treatment BIOM3G $50 \mathrm{~kg} /$ plant.

\section{ACKNOWLEDGMENT}

This research was made possible with the support of funding through the National Priorities Research Programs of Masterplan for Acceleration and Expansion of Indonesian Economic Development 2011-2025 (MP3EI) Fiscal Year 2013. 


\section{REFERENCES}

[1] B. Arifin, "Sustainable Oil Palm Development: Challenges for Food Security," in Presentation of The 7th Indonesian Palm Oil Conference and 2012 Price Outlook: "Sustainable Palm Oil Drivers of Change", Bali, November 30th - December 2nd, 2011.

[2] S.Tanaka, S. Tachibe, M.E.Wasli, J.Lat,L.Seman, J.J.Kendawang, K.Iwasaki, K. Sakurai, "Soil characteristics under cash crop farming in upland areas of Sarawak, Malaysia", Agriculture, Ecosystems and Environment, vol. 129, pp. 293-301, 2009.

[3] R.K. Aggarwal, P. Kumar, J.F. Power, "Use of crop residue and manure to conserve water and enhance nutrient availability and pearl millet yields in an arid tropical region," Soil and Tillage Research, vol. 41, pp. 43-51, 1997.

[4] F. Bastida, E. Kandeler, J.L. Moreno, M. Ros, C. García, T. Hernández, "Application of fresh and composted organic wastes modifies structure, size and activity of soil microbial community under semiarid climate,' Appl. Soil Ecol, vol. 40, pp. 318-329, 2008.

[5] A. Jeyabal, G. Kuppuswamy, "Recycling of organic wastes for the production of vermicompost and its response in rice-legume cropping system and soil fertility", European Journal of Agronomy, vol. 15 , pp. $153-170,2001$.
[6] R.D. Bardgett, P.J. Hobbs, A. Frostegard, "Changes in soil fungal: bacterial biomass ratios following reductions in the intensity of management of an upland grassland," Biol Fertil Soils, vol. 22, pp. 261-264, 1996.

[7] J. M. Bell, C. A. Robinson, R. C. Schwartz, "Changes in soil properties and enzymatic activities following manure applications to a rangeland," Rangeland Ecol Manage, vol. 59, pp. 314-320, 2006.

[8] S. Bittman, T. A. Forge, C. G. Kowalenko, "Responses of the bacterial and fungal biomass in a grassland soil to multi-year applications of dairy manure slurry and fertilizer," Soil Biol Biochem, vol. 37, pp. 613-623, 2005.

[9] T.W. Federle, D.C. Dobbins, J.R. Thornton-Manning, D.D. Jones, "Microbial biomass, activity, and community structure in subsurface soils", Ground Water, vol. 24, pp. 365-374, 1986.

[10] H.D. Foth, Fundamentals of Soil Science, $8^{\text {th }}$ ed., New York: John Wiley \& Sons, Inc, 1990. 